\title{
Prevalence of Late Preterm and Early Term Birth in Portugal
}

\section{Parto Pré-Termo Tardio e de Termo Precoce em Portugal}

Joana G. BARROS $\rrbracket^{1}$, Nuno CLODE ${ }^{1}$, Luís M. GRAÇA ${ }^{1,2}$

Acta Med Port 2016 Apr;29(4):249-253 - http://dx.doi.org/10.20344/amp.6523

\section{ABSTRACT}

Introduction: Late preterm birth (defined as birth between 34 and 36 complete weeks' gestation) and early term birth (defined as birth between 37 and 38 complete weeks' gestation) have become a topic of recent discussion as the morbidity associated with delivery at these gestational ages has become increasingly evident. Our objective was to evaluate the characteristics of late preterm and early term birth in Portugal.

Material and Methods: We developed a survey questionnaire that was sent to the Obstetric Department of all public hospitals in Portugal. The questionnaire consisted on questions on prevalence and mode of delivery of late preterm and early term period and associated neonatal morbidity and mortality. The questions referred solely to single births occurred during 2013.

Results: We received completed questionnaires from 14 hospitals, corresponding to nearly one third (33.5\%) of total deliveries in Portugal. We report $5.4 \%$ of late preterm and $27 \%$ of early term deliveries. Approximately two thirds of late preterm and three quarters of early term deliveries were spontaneous. The cesarean section rate was higher in late preterm (39.1\%) than in early term $(26.4 \%)$ births. Neonatal complications were more frequent in late preterm neonates (34.2\%) when compared to early term neonates (14.2\%). Discussion: The prevalence of late preterm and early term birth in our cohort is comparable, although slightly reduced, to other published series.

Conclusion: The obstetric community should raise efforts to limit deliveries below 39 weeks' gestation to the ones with a valid medical indication.

Keywords: Infant Mortality; Infant, Premature; Portugal; Premature Birth; Prevalence; Surveys and Questionnaires.

\section{RESUMO}

Introdução: Nos últimos anos, vários autores evidenciaram a morbilidade associada aos partos ocorridos entre as 34 e 36 semanas (pré-termo tardio) e entre as 37 e 38 semanas de gestação (termo precoce). Neste sentido, pretendemos realizar um estudo epidemiológico dos partos que ocorrem nestas idades gestacionais, em Portugal.

Material e Métodos: Realizámos um inquérito, que foi aplicado a todos os hospitais públicos de Portugal, acerca da prevalência e via de parto nos partos pré-termo tardios e de termo precoce, e morbilidade e mortalidade neonatal associada. As questões referiam-se apenas a gestações de feto único e a partos ocorridos em 2013.

Resultados: Incluímos 14 hospitais, correspondendo a 33,5\% dos partos ocorridos em Portugal, em 2013. Verificámos que 5,4\% dos partos ocorreram no período pré-termo tardio e $27 \%$ no termo precoce. Aproximadamente dois terços dos partos pré-termo tardio e três quartos dos partos de termo precoce foram espontâneos. A taxa de cesariana foi mais elevada entre as 34 e 36 semanas de gestação $(39,1 \%)$ do que entre as 37 e 38 semanas $(26,4 \%)$. As complicações neonatais foram mais frequentes após um parto prétermo tardio $(34,2 \%)$, quando comparadas com os de termo precoce $(14,2 \%)$.

Discussão: Na nossa amostra, a prevalência de parto pré-termo tardio e de termo precoce, ainda que ligeiramente inferior, é comparável à publicada em estudos anteriores.

Conclusão: É importante que a comunidade obstétrica nacional adote atitudes no sentido de limitar os partos antes das 39 semanas de gestação. Assim, nestas idades gestacionais os partos devem possuir uma indicação médica válida.

Palavras-chave: Mortalidade Infantil; Nascimento Prematuro; Portugal; Prematuro; Prevalência; Questionários.

\section{INTRODUCTION}

In 1969, the World Health Organization defined preterm delivery as birth occurring before 37 weeks' gestation. ${ }^{1}$ This implied a level of fetal maturity beyond which morbidity should be negligible. However, recent research has shown that significant morbidity persists at term, more specifically between the 37 and 38 complete weeks, ${ }^{2-4}$ which has led to the recent concept of 'early term' birth to describe deliveries at these gestational ages. ${ }^{5}$

Over time, as the survival of preterm infants improved, the phrase 'near term' acquired a physiologic connotation, perhaps related to the fact that antenatal steroids to enhance fetal lung maturation are only recommended until the 34 completed week's gestation. ${ }^{6}$ However, it has been recognized that the infants born between the $34^{\text {th }}$ and $36^{\text {th }}$ weeks' gestation are at a significantly increased risk for adverse neonatal outcomes, compared with term infants, which prompted the definition of 'late preterm' by participants at a 2005 workshop of the Eunice Kennedy Shriver National Institutes of Child Health. ${ }^{7}$

In recent years, morbidity associated with delivery at late preterm and early term has become increasingly evident in literature. ${ }^{2,3,5,8-10}$ In countries where this issue has been addressed, the knowledge of prevalence, risk factors, as well as maternal and neonatal morbidity and mortality associated with late preterm and early term birth, allowed the implementation of strategies in order to improve

\footnotetext{
1. Department of Obstetrics and Gynecology. Santa Maria University Hospital. Lisbon. Portugal.

2. Faculty of Medicine. University of Lisbon. Academic Center of Medicine. Lisbon. Portugal.

$\triangle$ Autor correspondente: Joana G. Barros. joanagmb@gmail.com

Recebido: 16 de abril de 2015 - Aceite: 16 de dezembro de 2015 | Copyright @ Ordem dos Médicos 2016
} 
the outcomes for women and newborn infants of these gestational age groups, while limiting these situations to a minimum. ${ }^{10-12}$

In Portugal, we are still not aware of our reality concerning late preterm and early term births. Therefore, our aim was to evaluate the epidemiology of late preterm and early term birth in Portugal, analyzing its prevalence, etiology and mode of delivery, as well as neonatal complications at these gestational ages.

\section{MATERIAL AND METHODS}

We developed a survey questionnaire that was sent by email to the Head of Obstetric Department of all 44 public hospitals in Portugal with 'perinatal support' and 'differentiated perinatal support'. The former, can provide basic care to newborns and support high risk pregnancies after 32 weeks; the later are tertiary care hospitals able to provide care to neonates and pregnant women of all gestational ages, including the ones needing neonatal surgery or other differentiated subspecialties. Also, they are equipped with a Neonatal Intensive Care Unit.

The questionnaire consisted on 30 questions divided in five different topics: general information regarding the institution; late preterm and early term deliveries; route of delivery in late preterm and early term births; neonatal morbidity in late preterm and early term infants; and neonatal mortality in late preterm and early term infants. We considered obstetrical indications for iatrogenic delivery the complications of maternal diabetes, maternal hypertensive disorders, other maternal indication, spontaneous premature rupture of membranes, anomalies of placentation, fetal growth restriction, congenital fetal anomalies and 'no indication registered or other indications'. We limited the elective cesarean sections indications to previous uterine scar, anomalies of placentation, suspicion of fetal hypoxia before labor (including fetal growth restriction), abnormal fetal presentation, congenital fetal anomalies, and 'no indication registered or other indications'. Also, we evaluated the duration of neonatal hospitalization after birth, and the neonatal admission to a Neonatal Intensive Care Unit (NICU). Neonatal complications were grouped into four generalized categories: metabolic complications (including feeding problems, hyperbilirrubinemia and hypoglycemia); respiratory complications; infectious complications; and neurologic complications (including seizures).

In the beginning of the questionnaire, it was explicit that all questions referred solely to single gestations and births occurred during 2013. The questionnaires were received in April 2014 and the answers returned until the end of July 2014.

\section{RESULTS}

From the 44 hospitals, only $14(31,8 \%)$ returned the questionnaires. Five were from the north region of Portugal (four from hospitals with differentiated perinatal support), four were from the center region (two from hospitals with differentiated perinatal support) and five were from the south region (three from hospitals with differentiated perinatal support). Considering the total number of single deliveries in the 14 institutions, it corresponded to nearly one third $(33.5 \%)$ of total deliveries in Portugal in the same period (27526 of single births reported from the participating institutions and 82064 of total deliveries in Portugal). ${ }^{14}$ The absolute mean of single deliveries per hospital was 1966 (SD \pm 621 ), with a maximum of 3516 and a minimum of 1030 single deliveries, with both these hospitals located in the south region of Portugal.

The absolute mean number of late preterm deliveries was 109 (SD \pm 42 ), which corresponded to $5.4 \%$ of total single deliveries in our sample. On the other hand, the absolute mean number of early deliveries was 550 (SD \pm 194 ), which corresponded to $27 \%$ of total single deliveries in our sample.

Approximately two thirds of late preterm deliveries were spontaneous $(66.7 \%)$. The most common indication for iatrogenic delivery between 34 and 36 completed weeks was preterm premature rupture of membranes (15\%) (Table 1). Concerning the iatrogenic indications, there were two

Table 1 - Spontaneous labor and causes of iatrogenic labor in late preterm and early term births

\begin{tabular}{lcc}
\hline & Late preterm (\%) & Early term (\%) \\
\hline Spontaneous labor & 66.7 & 74.8 \\
latrogenic labor* & & 6.7 \\
$\quad$ Premature rupture of membranes & 15.4 & 1.8 \\
Placental abnormalities & 5.5 & 3.8 \\
Fetal growth restriction & 6.9 & 0.2 \\
Fetal anomalies & 0.3 & 4.8 \\
Hipertensive complications & 8.0 & 2.8 \\
Diabetes complications & 3.1 & 3.0 \\
Other maternal indications & 2.4 & 5.6 \\
$\quad$ No indication registered / other indication & 4.0 & \\
\hline${ }^{*}$ Causes of iatrogenic labor are not always mutually exclusive & & \\
\end{tabular}


institutions that did not completed the questionnaire.

We report nearly three quarters of spontaneous deliveries among the early term births (74.8\%). The most common indications for iatrogenic delivery in this gestational age group were premature rupture of membranes $(6.7 \%)$, no indication and/or other indications (5.6\%) and maternal hypertensive complications $(4.8 \%)$ (Table 1$)$. Concerning the iatrogenic indications, there were three institutions that did not completed the questionnaire.

In our sample, the global cesarean section rate was $28.8 \%$. Considering the deliveries between 34 and 36 completed weeks, the cesarean section rate was $39.1 \%$ (Table 2). The most common indication for elective cesarean delivery in the late preterm group was 'no indication registered or other indication' (16\%), followed by suspicion of fetal hypoxia before labor (which included fetal growth restriction) (14.3\%) and abnormal fetal presentation (12.4\%). In the early term group, between 37 and 38 completed weeks, the cesarean section rate was $26.4 \%$ (Table 2). Again, the most common indication for elective cesarean delivery in the early term group was 'no indication registered or other indication' (18.1\%). Another frequent indications for elective cesarean delivery in this group were abnormal fetal presentation $(16.4 \%)$ and previous uterine $\operatorname{scar}(13 \%)$.

The mean total days of neonatal hospitalization were 6.5 days after a late preterm birth, comparing to 3.9 days after an early term birth. Concerning the neonatal admission to a NICU, we report $36.5 \%$ in the late preterm infants group and $7.7 \%$ in the early term infants group. Following a late preterm birth, the neonatal complications rate was $34.2 \%$; on the other hand, the complications rate after an early term birth was $14.2 \%$. The most common neonatal complications were metabolic in both groups $(25.5 \%$ in the late preterm infants and $7.6 \%$ in the early term group). Among the late preterm infants, $4 \%$ had to be re-admitted during the first 28 days after birth, as well as $3.4 \%$ of early term infants. The mortality rate was higher in infants born between 34 and 36 completed weeks (2.2\%o), comparing to infants born at 37 or 38 completed weeks $(0.6 \%$ ). Considering the questions of neonatal morbidity and mortality, there were three institutions that did not completed the questionnaire.

\section{DISCUSSION}

The epidemiology of late preterm and early term birth has been subject of intense research in recent years..$^{5,8-10}$ Nonetheless, in Portugal, this is the first study to date aiming to determine the prevalence of deliveries in these gestational ages. In our cohort, $5.4 \%$ of total single deliveries occurred in late preterm and $27 \%$ in early term period. These frequencies are both relatively reduced when compared to other studies. ${ }^{8,10,15,16}$ On the other hand, in the United States of America, the rate of late preterm deliveries was $7 \%$, and the rate of early term deliveries were $24.5 \%$, in the same period of study. ${ }^{17}$

The rate of spontaneous delivery was higher in early term births $(74.8 \%)$ when compared to late preterm births $(66.7 \%)$. This finding is in line with other studies, although our rate of spontaneous delivery in late preterm births was higher than the reported by other authors, namely McIntire and Leveno, ${ }^{18}$ in which approximately $45 \%$ of late preterm deliveries were attributed to idiopathic labor. Although our reported rates of spontaneous deliveries are more encouraging than others previously reported, we can deduce that a substantial fraction of late preterm and early term deliveries were iatrogenic/medically indicated (nearly $1 / 4$ of early term and $1 / 3$ of late preterm deliveries). In our cohort, the most common indication of iatrogenic delivery in both groups was (preterm) premature rupture of membranes. We chose to highlight this indication separated from spontaneous labor since the management of preterm premature rupture of membranes remains controversial, especially between 34 and 36 weeks' gestation. ${ }^{19}$ Considering the iatrogenic deliveries before 39 weeks' gestation, although there are some indications that are well established, there still remain some less well-defined indications in which the judgment of the physician must determine the timing of the delivery, and perhaps these unclear indications are the ones that could be reduced, avoiding unintended maternal and neonatal complications. ${ }^{20-22}$

The cesarean section rate in the late preterm group $(39.1 \%)$ was substantially higher than in the early term group $(26.4 \%)$. These rates raise concern, since delivery by cesarean section is an important independent risk factor for respiratory morbidity in term infants..$^{3,5,18}$ Particularly,

Table 2 - Cesarean section rate and indications for elective cesarean delivery in late preterm and early term births

\begin{tabular}{lcc}
\hline & Late preterm (\%) & Early term (\%) \\
\hline Cesarean section rate & 39.1 & 26.4 \\
Elective cesarean section* & & 13 \\
Previous uterine scar & 6.4 & 3.5 \\
Placental abnormalities & 6.7 & 16.5 \\
Abnormal fetal presentation & 12.4 & 3.9 \\
Suspicion of fetal hypoxia before labor & 14.4 & 0.6 \\
Fetal anomalies & 0.6 & 18.1 \\
No indication registered / other indication & 16 & \\
\hline${ }^{*}$ Causes of elective cesarean section are not always mutually exclusive. & & 16.6 \\
\hline
\end{tabular}


the cesarean rate between 34 and 36 weeks' gestation is considerably higher than the mean cesarean section rate for all gestational ages, which might be related to the lower spontaneous labor in this gestational age group. Unfortunately, in both groups of study, the most common indication for elective cesarean delivery was 'no indication registered or other indication', and this does not allow us to draw any clear conclusion about which indication contributed more to these cesarean section rates, although it underlines that presumably part of these didn't have an evident foundation. Nevertheless, in both groups the abnormal fetal presentation was a frequent indication for cesarean section $(12.4 \%$ in late preterm and $16.4 \%$ in early term deliveries). Additionally, in the late preterm group, another frequent indication was suspicion of fetal hypoxia before labor (including fetal growth restriction) (14.3\%), and in the early term group, previous uterine scar $(13 \%)$ was also frequently reported. These three common indications could, in some cases, be preventable, so efforts should be made to perform external cephalic version when it is indicated, improve the diagnosis and management of fetal growth restriction, and avoid cesarean section in nulliparous women as well as delay and implement methods of labor induction in women with previous uterine scar.

Considering the neonatal complications after late preterm and early term delivery, we found a prolonged hospitalization in both groups (6.5 days for late preterm and 3.9 days for early term neonates), when compared to the maximum length hospital stay expected of 72 hours after delivery. Moreover, we report a $4 \%$ rate of re-admission in late preterm infants and $3.4 \%$ in early term infants. This denotes the elevated potential of these conditions for neonatal complications, and other authors have also reported it. ${ }^{23-26}$

In our cohort, the admission to a NICU was almost five times greater in the late preterm neonates, comparing to early term neonates. This finding is in line with previous studies, which found a stepwise reduction in the rate of NICU admissions from 34 through 39 weeks, 8,16,24,26,27 with a significant decrease demonstrated between 34 and 36 weeks. ${ }^{27}$ Similarly to other studies recently published, ,40,15,16,24,26-29 our results show an association between late preterm and early term birth with neonatal mortality and short-term complications, which is clearly more evident in the first group. Nevertheless, neonatal mortality rates in each gestational age group were both relatively reduced comparing to other published studies, an encouraging marker for our country. ${ }^{10,15,24}$

Our data have several limitations. Although this is a population-based cohort study, our data only refers to nearly one third of the total births in the same period, which might limit possible generalizations of our findings. Additionally, this is a retrospective study, and our data was collected in several institutions, possibly reflecting inconsistency of obstetric and pediatric care between hospitals. In addition, in each institution, a different person carried out data collection and this might also have contributed to some information bias.

Because this is the first study to date aiming late preterm and early term deliveries in Portugal, we cannot evaluate trends of prevalence of births in these gestational ages. Nevertheless, it is an important finding that in our cohort, the prevalence of late preterm and early term deliveries, although not negligible, is relatively reduced when compared to other published series. Even so, it cannot be over emphasized that it is crucial to determine the individual cases in which the dangers of continuing the pregnancy because of valid medical complications is significant and justifies delivery before full term. Thus, when promoting a reduction in late preterm and early term deliveries, the target practice is the ones occurring without medical indication, and that occasional indicated deliveries between 34 and 38 weeks remains an important part of good obstetric care.

\section{CONCLUSIONS}

With this study, we evaluated the prevalence of late preterm and early term births in Portugal, and found an estimate of $5.4 \%$ of deliveries occurring between 34 and 36 weeks of gestation and $27 \%$ during 37 and 38 weeks. We believe that our data compel future research in this field, in order to better understand the etiology of labor and mode of delivery in these gestational ages, and to better evaluate neonatal complications arising from late preterm and early term deliveries. Moreover, it is expected that following our findings, the obstetric community raise efforts to limit deliveries below 39 weeks' gestation to the ones with a valid medical indication.

\section{ACKNOWLEDGMENTS}

The authors would like to thank the Department of Obstetrics and Gynecology of Hospital de Guimarães, Hospital de Portimão, Hospital de Aveiro, Maternidade Bissaya Barreto, Maternidade Dr. Daniel de Matos, Hospital Center - Entre-o-Douro-e Vouga, Maternidade Dr. Alfredo da Costa, Hospital Santa Maria, Hospital de Leiria, Hospital de São João, Hospital de Viseu, Hospital Center of Vila Nova de Gaia/Espinho, Hospital de Faro, Hospital de Beja and Hospital Pedro Hispano, for the collaboration in this study. Particularly, the authors would like to thank Alina Seixas, Ana Correia de Campos, Ana Edral, Andreia Fonseca, Cátia Ferreira, Claudina Carvalho, Daniela Vila Real, Fernando Guerreiro, Filipa Rafael, F. Nogueira Martins, Helena Fachada, Inês Dias, Joana Sousa, Joana Félix, João Rosa, Luísa Dias, Maria Carlota Cavazza, Maria Céu Almeida, Maria Inês Marques, Maria José Janeiro, Maria Martins Boia, Mário Oliveira, Nuno Montenegro, Olga Viseu, Paulo Moura, Sara Vargas, Sofia Mendes, Tatiana Leite and Teresa Paula Teles, for the effort in collecting the data.

\section{PROTECTION OF HUMANS AND ANIMALS}

The authors declare that the procedures were followed according to the regulations established by the Clinical Research and Ethics Committee and to the Helsinki 
Declaration of the World Medical Association.

\section{DATA CONFIDENTIALITY}

The authors declare having followed the protocols in use at their working center regarding patient's data publication.

\section{REFERENCES}

1. World Health Organization. Prevention of Perinatal morbidity and mortality. Public Health Papers.42.Geneva: WHO;1969.

2. Reddy UM, Bettegowda VR, Dias T, Yamada-Kushnir T, Ko CW, Willinger M. Term Pregnancy: a period of heterogeneous risk for infant mortality. Obstet Gynecol. 2011;117:1279-87.

3. Tita AT, Landon MB, Spong CY, Lai Y, Leveno KJ, Varner MW, et al. Timing of elective repeat cesarean delivery at term and neonatal outcomes. N Eng J Med. 2009;360:111-20.

4. Gibson KS, Waters TP, Bailit JL. Maternal and neonatal outcomes in electively induced low-risk term pregnancies. Am J Obstet Gynecol. 2014;211:249.e1-16.

5. Engle WA, Kominiarek M. Late preterm infants, early term infants, and timing of elective deliveries. Clin Perinatol. 2008;35:325-41.

6. Roberts D, Dalziel S. Antenatal corticosteroids for accelerating fetal lung maturation for women at risk of preterm birth. Cochrane Database Syst Rev. 2006;3:CD004454.

7. Raju TN, Higgins RD, Stark AR, Leveno KJ. Optimizing care and outcome for late-preterm (near-term) infants: A summary of the workshop sponsored by the National Institute of Child Health and Human Development. Pediatrics. 2006;118:1207-14.

8. Ananth CV, Friedman AM, Gyamfi-Bannerman C. Epidemiology of moderate preterm, late preterm and early term delivery. Clin Perinatol. 2013:40:601-10.

9. Gyamfi-Bannerman C. The scope of the problem: the epidemiology of late preterm and early-term birth. Semin Perinatol. 2011;35:246-8.

10. Shapiro-Mendoza CK, Lackritz EM. Epidemiology of late and moderate preterm birth. Semin Fetal Neonatal Med. 2012;17:120-5.

11. Clark SL, Frye DR, Meyers JA, Belfort MA, Dildy GA, Shalece K, et al. Reduction in elective delivery at $<39$ weeks of gestation: comparative effectiveness of 3 approaches to change and the impact on neonatal intensive care admission and stillbirth. Am J Obstet Gynecol. 2010;203:449.e1-6.

12. Donovan EF, Lannon C, Bailit J, Rose B, lams JD, Byczkowski T. A statewide initiative to reduce inappropriate scheduled births at 36(0/7)38(6/7) weeks' gestation. Am J Obstet Gynecol. 2010;202:243.e1-8.

13. Oshiro BT, Henry E, Wilson J, Branch DW, Varner MW. Decreasing elective deliveries before 39 weeks of gestation in an integrated health care system. Obstet Gynecol. 2009;113:804-11.

14. www.pordata.pt. PORDATA: Base de dados Portugal contemporâneo; Fundação Francisco Manuel dos Santos; [consultado 2014 Nov 10]. Disponivel em http://www.pordata.pt.

15. Machado LC, Passini R, Rosa IR, Carvalho HB. Neonatal outcomes of

\section{CONFLICTS OF INTEREST}

The authors declare that there are no conflicts of interest.

\section{FUNDING SOURCES}

The authors report no financial support.

late preterm and early term birth. Eur J Obstet Gynecol Reprod Biol. 2014;179:204-8.

16. Parikh LI, Reddy UM, Männistö T, Mendola P, Sjaarda L, Hinkle S, et al. Neonatal outcomes in early term birth. Am J Obstet Gynecol. 2014;211:265.e1-11

17. Martin JA, Hamilton BE, Osterman MJ, Curtin SC, Mathews TJ. Births: Final Data for 2013. Natl Vital Stat Rep. 2015;64:1-64.

18. Mclntire DD, Leveno KJ. Neonatal mortality and morbidity rates in late preterm births compared with births at term. Obstet Gynecol. 2008;111:35-41.

19. Fuchs K, Gyamfi C. The influence of obstetric practices on late prematurity. Clin Perinatol. 2008;35:343-60.

20. Spong CY, Mercer BM, D'alton M, Kilpatrick S, Blackwell S, Saade G. Timing of indicated late-preterm and early-term birth. Obstet Gynecol. 2011;118:323-33

21. Raju TN. Moderately preterm, late preterm and early term infants: research needs. Clin Perinatol. 2013;40:791-7.

22. Clark SL, Meyers JA, Perlin JB. Oversight of elective early term deliveries: avoiding unintended consequences. Am J Obstet Gynecol. 2012;206:387-9.

23. Shapiro-Mendoza CK, Tomashek KM, Kotelchuck M, Barfield W, Nannini A, Weiss J, et al. Effect of late-pretem birth and maternal medical conditions on newborn morbidity risk. Pediatrics. 2008;121:e223-32.

24. Engle WA. Morbidity and mortality in late preterm and early term newborns: a continuum. Clin Perinatol. 2011;38:493-516.

25. Escobar GJ, Greene JD, Hulac P, Kincannon E, Bischoff K, Gardner MN, et al. Rehospitalisation after birth hospitalisation: patterns among infants of all gestations. Arch Dis Child. 2005;90:125-31.

26. Sengupta S, Carrion V, Shelton J, Wynn RJ, Ryan RM, Singhal K, et al. Adverse neonatal outcomes associated with early-term birth. JAMA Pediatr. 2013;167:1053-9.

27. Lubow JM, How HY, Habli M, Maxwell R, Sibai B. Indications for delivery and short-term neonatal outcomes in late preterm as compared with term births. Am J Obstet Gynecol. 2009;200:e30-3.

28. Ghartey K, Coletta J, Lizarraga L, Murphy E, Ananth CV, GyamfiBannerman C. Neonatal respiratory morbidity in the early term delivery. Am J Obstet Gynecol. 2012;207:292.e1-4.

29. Bastek JA, Sammel MD, Paré E, Srinivas SK, Posencheg MA, Elovitz MA. Adverse neonatal outcomes: examining the risks between preterm, late preterm, and term infants. Am J Obstet Gynecol. 2008;199:e1-367. e8. 